Trinity University

Digital Commons@ Trinity

History Faculty Research

History Department

$12-2005$

\title{
Atlantic Intersections: Early American Commerce and the Rise of the Spanish West Indies (Cuba)
}

Linda K. Salvucci

TrinityUniversity, lsalvucc@trinity.edu

Follow this and additional works at: https://digitalcommons.trinity.edu/hist_faculty

Part of the History Commons

\section{Repository Citation}

Salvucci, L.K. (2005). Atlantic intersections: Early American commerce and the rise of the Spanish west Indies (Cuba). Business

History Review, 79(4), 781-809. doi: 10.2307/25097114

This Article is brought to you for free and open access by the History Department at Digital Commons @ Trinity. It has been accepted for inclusion in History Faculty Research by an authorized administrator of Digital Commons@ Trinity. For more information, please contact jcostanz@trinity.edu. 


\title{
Linda K. Salvucci
}

\section{Atlantic Intersections: Early American Commerce and the Rise of the Spanish West Indies (Cuba)}

\begin{abstract}
An Atlantic approach to the history of early American trade challenges traditional British opinions and, indeed, much AngloAmerican scholarship regarding the commercial prospects of the new United States. Contemporary Spanish observations, in contrast to the more familiar and widely cited ones in English, correctly predicted the post-Revolutionary War integration of American and Spanish imperial markets. As political, diplomatic, and economic upheavals broke down the old mercantilist system, U.S. merchants quickly succeeded in exploiting their comparative advantage in the expanding Atlantic economy. The debate over the "decline" of the British West Indies is amplified by examining the concurrent "rise" of the Spanish West Indies, particularly Cuba, in the late eighteenth and early nineteenth centuries.
\end{abstract}

$\mathrm{O}$

ver the last few years the field of "Atlantic history" has become much more than an "idea": it is now an area of historical scholarship forthrightly defined and practiced, thanks in no small part to Bernard Bailyn and his International Seminar on the History of the Atlantic World at Harvard University. While many of the new projects focus upon movements of specific peoples and ideologies around the Atlantic basin, an Atlantic approach offers exciting new avenues of inquiry and

LINDA K. SALVUCCI is associate professor of history at Trinity University in San Antonio, Texas.

The author would like to thank Bernard Bailyn, Mary Gallagher, Eunice Herrington, Michael Jarvis, John McCusker, Elizabeth Nuxoll, Richard Salvucci, and three anonymous referees for their assistance and encouragement. Preliminary versions of parts of this essay were presented at the August 1997 International Seminar on the History of the Atlantic World at Harvard University, at the Conference on "Founding Financier Robert Morris" at the Graduate Center of the City University of New York in April 2000, and at "What If? Counterfactualism in Early American History," a conference held at Princeton University in March 2001.

Business History Review 79 (Winter 2005): 781-810. (C) 2005 by The President and Fellows of Harvard College. 
insight for the study of trade. ${ }^{1}$ Not only does a multilateral perspective broaden the basic story of the exchange of commodities; it also prompts specialists in traditional fields defined by nationality to reformulate long-standing assumptions and explanations. This is especially the case regarding the commercial prospects, perceived and real, of the new United States. Conventional Anglo-American historiography suggests that these prospects were bleak indeed, especially in the years immediately after the American Revolution. Following the lead of John Baker Holroyd, Lord Sheffield, historians have focused upon Great Britain, France, and their remaining colonies as the major foreign trading partners of the thirteen colonies/states. However, it has become increasingly clear that informed contemporaries regarded ports throughout the Spanish Empire, particularly those in Cuba, as desirable and lucrative destinations for American exports and as sources of valuable imports, such as specie. Many American merchants, including Robert Morris, the first superintendent of finance, traded with Spanish imperial ports for public and private gain. For these U.S. traders, Cuba quickly emerged as a dynamic substitute market for the British and French West Indies. Their wartime and post-Revolutionary experiences, in turn, paved the way for exploiting the unprecedented opportunities of the Napoleonic era.

\section{Early American Commerce with Cuba}

American economic historians are often wary of the late eighteenth century, considering it a statistical dark age due to large and frequent gaps in the quantitative record. However, materials from previously

\footnotetext{
${ }^{1}$ For the "idea" of Atlantic history and a current appraisal of the field, see Bernard Bailyn, Atlantic History: Concept and Contours (Cambridge, Mass., 2005). A very useful recent introduction is "Round Table Conference: The Nature of Atlantic History," Itinerario, 23 (1999): 48-173. Also see David Armitage and Michael J. Braddick, eds., The British Atlantic World, 1500-1800 (New York, 2002), particularly Armitage's essay, "Three Concepts of Atlantic History," 11-27, as well as Nicholas Canny, "Writing Atlantic History; or Reconfiguring the History of Colonial British America," Journal of American History 86 (Dec. 1999): 1093114, and the wider-ranging essays in Christine Daniels and Michael V. Kennedy, eds., Negotiated Empires: Centers and Peripheries in the Americas, 1500-1820 (New York, 2002).

See the special issue, "The Atlantic Economy in an Era of Revolutions," William and Mary Quarterly, 3rd ser., 62 (July 2005), for admirable efforts to move beyond an AngloAmerican frame of reference. Economic historians have employed an Atlantic approach, most frequently and impressively with regard to studies of slavery and the slave trade; see David Eltis, Economic Growth and the Ending of the Transatlantic Slave Trade (New York, 1987), and, more recently, The Rise of African Slavery in the Americas (Cambridge, 2000). For Anglo-American trade and finance, see John J. McCusker and Kenneth Morgan, eds., The Early Modern Atlantic Economy (Cambridge, 2000), as well as John J. McCusker, Essays in the Economic History of the Atlantic World (New York, 1997), and David Hancock, "The British Atlantic World: Coordination, Complexity, and the Emergence of an Atlantic Market Economy, 1651-1815," Itinerario 23 (1999): 107-26.
} 


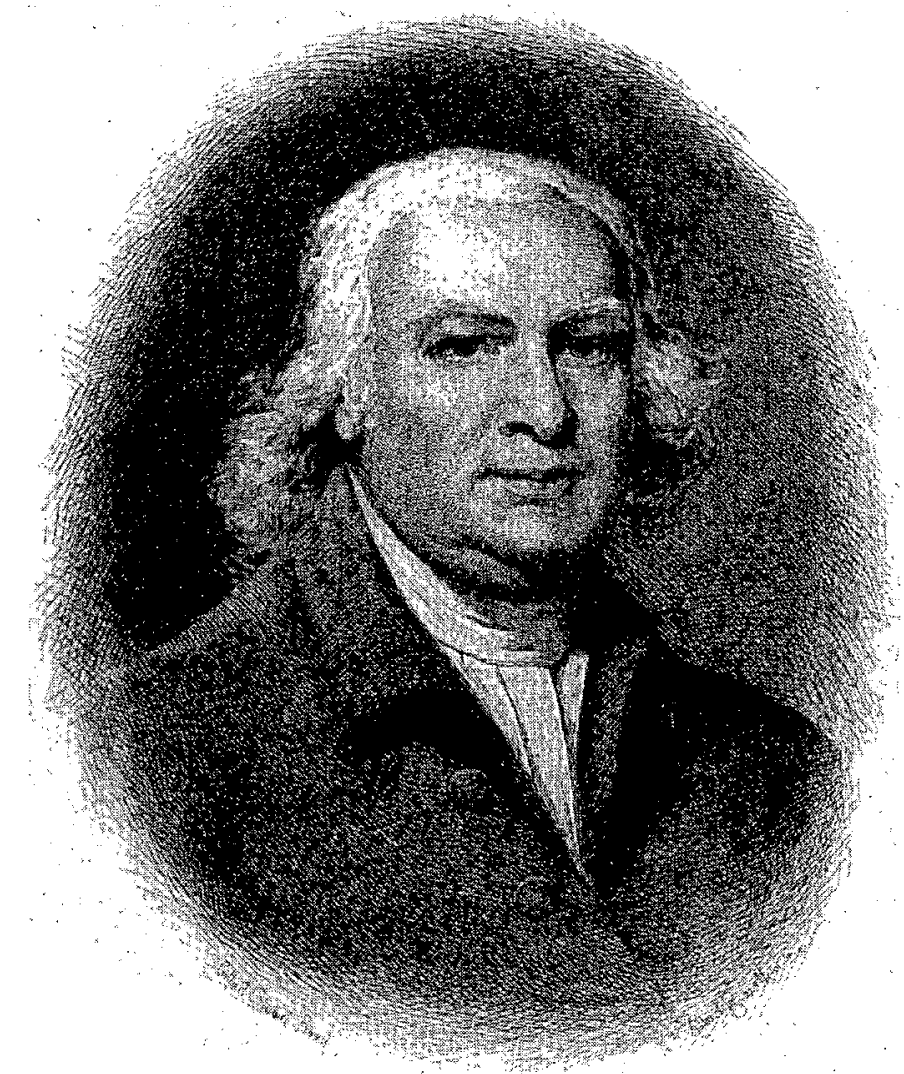

Etching of Robert Morris by Albert Rosenthal after a portrait by Gilbert Stuart, n.d. From the Society Portrait Collection. Courtesy of The Historical Society of Pennsylvania. As a longtime private trader and the first superintendent of finance of the United States, Morris had a particular interest in the North American trade with Cuba before and after independence.

unexploited Spanish archives add some quantitative and much qualitative data. Along with newly published sources in English, specifically The Papers of Robert Morris, they signal an improved understanding of the nature and origins of commercial ties between the thirteen colonies/states and Cuba. For example, even if quantitative estimates of the magnitude of the trade remain incomplete, it is clear that far more than occasional "smuggling" was involved on the eve of the American Revolution. ${ }^{2}$ These initial ventures are significant, moreover, because

${ }^{2}$ Severe inconsistencies in reporting and preserving records, coupled with shifting identifications of products ("cereals" vs. "wheat" vs. "flour"), volumes ("barrels" vs. "pounds"), and trading partners ("Pennsylvania" vs. "Philadelphia," "Spanish West Indies" vs. "Cuba") by the 
they paved the way for American domination of the Cuban market, first during the Napoleonic Wars, then after 1819, when Spain opened its "ever faithful isle" to "free trade."

How did a trader like Robert Morris become so interested in Cuba? Conventional wisdom points to the Anglo-American occupation of Havana for ten months toward the close of the Seven Years' War as a turning point in commercial relations between the British and Spanish colonies. However, new research by Sherry Johnson establishes that environmental crises in the late 1760 s and 1770 s sparked food shortages across the Caribbean, but particularly in Cuba, that led Spanish officials to grant unprecedented trading concessions to Morris and his business partner, Thomas Willing. ${ }^{3}$ Morris's firm was chosen because of its already extensive experience in both Spanish and non-Spanish Caribbean markets. By the mid-1770s, this trader and public servant anticipated that the demand for U.S. foodstuffs would only increase as the Revolutionary War persisted. In 1778, Morris shrewdly formed his business partnership with Juan de Miralles, a Spanish provisions merchant sent by Charles III to "observe" the Continental Congress. By the time Spain was pulled into the war a year later, Cuba's already increasing white population had swelled with imperial troops. These consumers preferred wheat-flour products, and peninsular and Spanish American suppliers simply could not meet the demand. Direct commerce between the North American mainland and the island was thus formally legitimized by the Spanish. The Philadelphia region began to exert its

respective governments, make it difficult to generate reliable quantitative estimates of the trade between the United States and Cuba before 1821 and certainly not for that commerce during the pre-Revolutionary years. Sometimes the number of ships traveling between ports is the best available proxy of early patterns of exchange, as used by Roy Nichols, "Trade Relations and the Establishment of United States Consulates in Spanish America, 1779-1809," Hispanic American Historical Review 8 (1933): 289-313. "Smuggling" is a term whose working definition shifted according to moment and circumstance. Specific shipments did, of course, violate the letter of changing national laws, or sometimes merely their spirit; accusations were levied that were with or without merit. At least the latter category generated legal documents that economic historians can utilize to elucidate the complexities of trade.

For indications of the composition and magnitude of the United States-Cuba trade following the American Revolution, see Linda K. Salvucci, "Supply, Demand and the Making of a Market: Philadelphia and Havana, 1780-1830," in Franklin W. Knight and Peggy K. Liss, eds., Atlantic Port Cities: Economy, Culture and Society in the Atlantic World, 1650-1850 (Knoxville, 1991): 40-57. For a creative approach to calculating post-Revolutionary trade, see Javier Cuenca Esteban, "Trends and Cycles in U.S. Trade with Spain and the Spanish Empire, 1790-1819," Journal of Economic History 44 (1984): 521-41. For analysis of the Cuba trade after 1821, when much better quantitative data are available, see Linda K. Salvucci and Richard J. Salvucci, "Cuba and the Latin American Terms of Trade in the Nineteenth Century: Old Theories, New Evidence," Journal of Interdisciplinary History 31 (Autumn 2000): 197-222.

${ }^{3}$ Sherry Johnson, "El Niño, Environmental Crisis, and the Emergence of Alternative Markets in the Hispanic Caribbean, 1760s-1770s," William and Mary Quarterly, 3rd ser., vol. 62 (July 2005): 365-410. 
comparative advantage over northern Spanish and Mexican grain producers, who were increasingly unable to compete. ${ }^{4}$ Not coincidentally, produce- and mail-laden ships belonging to Morris and Miralles were the very first to sail from Philadelphia to Havana. These early and successful ventures were cut short by Miralles's death the next year. However, his successor, Francisco Rendón, quickly extended new and lucrative provision contracts for Spanish troops in Cuba to Morris and to several other merchants from Pennsylvania and Maryland. ${ }^{5}$ The granting of favors was not one sided. In May 1782, when Rendón failed to receive remittances from home, Morris "offered him a supply of money." At the same time, Morris asked that Rendón support his request to protect U.S. trade, and the Spaniard promised to do so. ${ }^{6}$

This was neither the first nor the last example of Morris blending his "private" interests as a trader with his "public" responsibilities as the new superintendent of finance. ${ }^{7}$ Indeed, from the summer of 1781 onward, Morris was immersed in a series of complicated maneuvers to draw upon loans made to the United States by European powers by selling his bills of exchange at Havana, where he judged the rates would be most favorable for the Americans. ${ }^{8}$ For early American specialists, now able to follow the twists and turns of Morris's complex scheme, the Havana mission provides a nuts-and-bolts case study of the precarious nature of Revolutionary finances. Moreover, this transaction offers a sobering context for understanding the Continental Congress's sluggish support of its own army. ${ }^{9}$ Morris's urgency in securing specie, it turns out, was motivated not just by the obvious need for a circulating

\footnotetext{
${ }^{4}$ Fernando Barreda, Comercio marítimo entre los Estados Unidos y Santander (17781829) (Santander, 1950); Pablo Tornero Tinajero, "Comerciantes, hacendados y política mercantil en Cuba. La rivalidad Cádiz-Estados Unidos (1763-1800)," en Andalucia y América en el siglo XVIII: Actas de las IV jornadas de Andalucia y América (Seville, 1985), 119-45; Luís J. Ramos, "Navios extranjeros habilitados como nacionales para efectuar el comercio con América a mediados del siglo XVIII," and Demetrio Ramos Pérez, "El problema de los embarques de harinas en los registros para América," in Coloquio de Historia CanarioAmericana (1977), vol. 2 (Gran Canaria, 1979), 21-32, 35-44; Guy P. C. Thomson, Puebla de los Angeles: Industry and Society in a Mexican City, 1700-185o (Boulder, 1989).

${ }^{5}$ Light Townsend Cummins, Spanish Observers and the American Revolution, 17751783 (Baton Rouge, 1991), 126-28, 161-62, 174-75. On page 169, Cummins notes, "Because of Miralles, hundreds of Americans went to Havana in a growing commerce that provided significant contact between the Spanish colony and important North Atlantic ports."

${ }^{6}$ E. James Ferguson and John Catanzariti, eds., The Papers of Robert Morris, $1781-1784$, vol. 5 (Pittsburgh, 1980), 189-90.

${ }^{7}$ Mary A. Y. Gallagher, "Private Interest and the Public Good: Settling the Score for the Morris-Holker Business Relationship, 1778-1790," Pennsylvania History 69 (Spring 2002): 179-209.

${ }^{8}$ Morris laid out his plan in a letter to the Governor of Cuba in E. James Ferguson, The Papers of Robert Morris, 1781-1784, vol. 1 (Pittsburgh, 1973), 311-16.

${ }^{9}$ E. Wayne Carp, To Starve the Army at Pleasure: Continental Army Administration and American Political Culture, 1775-1783 (Chapel Hill, 1984).
} 
medium, but also by the desperate requirement to pay the Continental troops. The state assemblies and the Confederation Congress were not merely full of tight-fisted republicans reluctant to ante up the cash; there also simply was not enough hard currency in circulation to meet the obligations to George Washington's men. Thus, Morris sought to reassure the general on October 16, 1782, writing, "I know that some money is necessary, and my efforts to obtain it, both at home and abroad, have been unceasing. I am now about to purchase a vessel, and send a person on board of her to the Havanna [sic], for the purpose of vending bills of exchange to the amount of half a million dollars."

As an experienced private trader, the superintendent knew what most Latin Americanists take for granted: millions of pesos of Mexican silver flowed into Cuba each year under an imperial funding program known as the situado, or subvention. Even more specie than usual had accumulated in Havana as a result of war-induced blockades. ${ }^{11}$ Morris hoped to tap this enhanced supply, which could be used for general circulation in the United States and for enhancing the credit of the Bank of North America. Evidently some specie did manage to find its way north; by April 25, 1783, one of Morris's associates noted: "We have an immence [sic] sum of Specie in the different States-a very large proportion of it in the Massachusetts, Connecticut and this state [Pennsylvania]a great deal of which has been extracted from the Havannah, a large Sum from France, and no trifling sum from New York..."12 Interestingly, in Great Britain, Francis Baring, merchant and financial advisor to [William Petty Fitzmaurice], the Earl of Shelburne, the recent prime minister, discounted this report, because he could not imagine how the Americans would have been able to obtain the supply. ${ }^{13}$ This suggests that influential members of the British political establishment did not yet comprehend the scope and extent of the trade between their rebellious colonies and the Spanish West Indies.

But how was Morris able to find trustworthy individuals willing and able to carry out the tasks of negotiating through conflicting levels of the Spanish imperial bureaucracy in Cuba and then outrunning enemy attack ships on the trip home? Here again The Papers of Robert

${ }^{10}$ John Catanzariti and E. James Ferguson, eds., The Papers of Robert Morris, vol. 6 (Pittsburgh, 1984), 604.

${ }^{11}$ John Catanzariti, ed., The Papers of Robert Morris, vol. 7 (Pittsburgh, 1988), 497n13.

${ }^{12}$ Samuel Inglis and Co. to John and Francis Baring, Philadelphia, 25 Apr. 1783, in Catanzariti, ed., The Papers of Robert Morris, vol.7, p. 753.

${ }^{13}$ Baring's skepticism is referenced in Catanzari, ed., The Papers of Robert Morris, vol. 7, p. 716n1. However, Phineas Bond, the British consul resident in Philadelphia, estimated that over 500,000 pesos entered the port in 1787 alone: see Arthur P. Whitaker, "Reed and Forde: Merchant Adventurers of Philadelphia," Pennsylvania Magazine of History and Biography 61 (1937): 244-45. 
Morris provide much illuminating detail. The superintendent had to induce other experienced traders, such as John Barry and Oliver Pollock, to deliver the specie by allowing them to trade on their own accounts while carrying out his instructions for the public benefit. Several did manage to sell their own private cargoes in Havana and to pocket unknown profits that must have made the risks and demands of such ventures worthwhile. But Pollock ran into exceptional difficulties. At the start of 1783, when Spain threatened to revoke the Americans' direct trading privileges with Cuba, Morris hoped to have the well-connected Pollock recognized as the new U.S. commercial agent in Havana. The superintendent also wanted to help Pollock settle his considerable government accounts and personal debts through permitting the sale of his private cargoes of flour in Cuba. These proved to be conflicting goalsor else Pollock was far less lucky than his counterparts-when Spanish officials confiscated contraband goods in some of his flour barrels. True to form, the Havana bakers' guild managed to grab up the flour anyway, but Pollock never was recognized as the official U.S. agent. In fact, he ended up in prison the next year, as imperial bureaucrats now sought to repress direct American trade with Cuba. ${ }^{14}$

Their ability to do so was short lived. Though Morris himself went bankrupt and lost his government position, the genie, so to speak, had been let out of the bottle. Subsequent secretaries of finance and of the treasury did not directly engage in the Cuba trade, but numerous other Americans jumped at the opportunity to do so. Philadelphia merchants, such as John Leamy, used religious and family connections to great advantage to curry favor with Spanish officials and thus exploit this rapidly expanding market. ${ }^{15}$ In essence, they overcame risk by navigating cultural issues in the increasingly cosmopolitan and complex environment that led to the demise of mercantilism and the shift to free trade. Interests in Great Britain either ignored or denied the emergence of reciprocal trade advantages between the United States and Cuba, or perhaps they simply were not well advised. An Atlantic approach to analyzing the breakdown of the first British Empire calls into question the extent to which the former metropolis was able to control the trade of its ex-colonies.

\footnotetext{
${ }^{14}$ There is an admirable four-page head note in The Papers of Robert Morris that recounts Pollock's misadventures in the context of the impending postwar restrictions on direct trade between the United States and Spain's prized colony. Elizabeth M. Nuxoll and Mary A. Gallagher, eds., The Papers of Robert Morris, 1781-1784, vol. 8 (Pittsburgh, 1995), 62-65.

${ }^{15}$ For Leamy's trading career, see Linda K. Salvucci, “Anglo-American Merchants and Stratagems for Success in Spanish Imperial Markets, 1783-1807," in Jacques Barbier and Allan J. Kuethe, eds., The North American Role in the Spanish Imperial Economy, 17601819 (Manchester, 1984), 127-33, 214-17.
} 


\section{Lord Sheffield's Predictions from London}

Ever since John Baker Holroyd, Lord Sheffield, published his $O b-$ servations on the Commerce of the American States in 1783, American and British students of early United States history have portrayed the economic prospects of the new nation in a relentlessly pessimistic light. For example, Jeremy Atack and Peter Passell begin their survey of foreign trade and commercial policy in the development of the new nation as follows:

Independence from British rule did not immediately liberate the United States from mercantilist restrictions. Instead the United States merely switched from the role of active participant within the British imperial system to that of outsider in a world dominated by large mercantilist powers. This change did not bode well for the new nation. British markets were shut to American exporters, unprotected American shipping fell prey to pirates, and Spanish and French mercantilist regulations made it difficult to make up lost trade elsewhere in Europe. One might thus expect that the foreign trade sector that had loomed so large in late colonial development, especially in such port cities as Baltimore, Boston, New York, and Philadelphia, would have been hard hit.

This introductory paragraph then shifts gears with the surprising judgment, "If so, it soon recovered." ${ }^{16}$ Only then do the authors point out that the export trade of the new United States exceeded the impressive levels of the late colonial period by "perhaps 30 percent." Even in the absence of comprehensive serial data, conventional economic theory suggests the possibility of a rapid substitution of non-British Caribbean markets. Likewise, familiarity with the historical record of rapidly changing commercial circumstances during the Napoleonic Wars indicates extraordinary opportunities for U.S. traders within a decade of the signing of the Treaty of Paris. Yet, the tenor of Atack and Passell's initial remarks fixes the impression of doom and gloom. To be sure, their approach only mirrors that of the secondary literature they cite. ${ }^{17}$ These

${ }^{16}$ John Baker Holroyd, Lord Sheffield, Observations on the Commerce of the United States with Europe and the West Indies ... (London, 6th ed., 1784). This edition is the most frequently cited, probably because it contains an enlarged appendix and index. For the textbook quotation, see Jeremy Atack and Peter Passell, A New Economic View of American History from Colonial Times to 1940, 2nd ed. (New York, 1994), 112.

${ }^{17}$ Authors listed in Atack and Passell's bibliography include Donald R. Adams Jr., "American Neutrality and Prosperity, 1793-1808: A Reconsideration," Journal of Economic History 40 (1980): 713-37; Gordon C. Bjork, "The Weaning of the American Economy: Independence, Market Changes, and Economic Development," Journal of Economic History 24 (1964): 541-66; Claudia D. Goldin and Frank D. Lewis, "The Role of Exports in American Economic Growth during the Napoleonic Wars, 1793 to 1807," Explorations in Economic History 17 (1980): 6-25; Gary M. Walton and James F. Shepherd, The Economic Rise of 
works, in turn, reflect a widespread-at times exclusive-reliance upon the most accessible contemporary commentary published in English, Lord Sheffield's Observations.

The major points of this extensively cited source may be summarized as follows. In retaliation for American political independence, Lord Sheffield proposed an aggressive trade strategy that would render the United States a continued commercial vassal of Great Britain. How? In essence, he advocated that the newly independent United States be denied any benefits that accrued from trade with the remainder of the first British Empire. To prohibit mainland commerce with the British West Indies, he asserted, was to close off the most lucrative market for U.S. domestic exports. Lord Sheffield even alleged that American grain production was unimpressive and that it would not continue at high levels indefinitely. In his mind, then, the Jeffersonian dream of an agricultural republic was just that and nothing more. At the same time, Lord Sheffield fervently maintained that British merchants could easily flood the American market with manufactured goods, as well as provide superior shipping services.

In this last prediction of the postwar dumping of British goods, Lord Sheffield was proved correct. However, ongoing research in Atlantic history shows that he was much mistaken regarding the lack of alternative markets for U.S. domestic exports and the American capacity to increase grain production. Recent publication of The Wealth of Nations notwithstanding, Lord Sheffield's vision remained clouded by mercantilist or neomercantilist impulses. ${ }^{18}$ He staunchly defended imperial Great Britain and its Navigation Acts, articulating the negative side of what became a vigorous parliamentary debate over the relaxation of

Early America (Cambridge, 1979). Curtis P. Nettles, The Emergence of a National Economy, $1775-1815$ (New York, 1962), is the standard overview.

Other treatments that offer similar interpretations but are not cited by Atack and Passell include John J. McCusker and Russell R. Menard, The Economy of British America, 16071789 (Chapel Hill, 1985); and Ronald Hoffman, John J. McCusker, Russell Menard, and Peter J. Albert, eds., The Economy of Early America: The Revolutionary Period, 1763-1790 (Charlottesville, 1988).

A fuller picture emerges when the above are read in conjunction with John $\mathrm{H}$. Coatsworth, "American Trade with European Colonies and the Caribbean and South America, 1790-1812," William and Mary Quarterly, 3rd ser., 24 (1967): 243-66; and F. Crouzet, "Variations on the North American Triangle from Yorktown to Waterloo: Substitution, Complementarity, Parallelism," in Charles P. Kindleberger and Guido di Tella, eds., Economics in the Long View: Essays in Honor of W. W. Rostow, 3 vols. (New York, 1982), vol. 2, pp. 4466. Also see the older but still useful Anna C. Clauder, American Commerce as Affected by the Wars of the French Revolution and Napoleon, 1793-1812 (Philadelphia, 1932); and Helen Louise Klopfer, "Statistics of the Foreign Trade of Philadelphia, 1700-1860" (MSS. at the Eleutherian-Mills Historical Library, 1937).

${ }^{18}$ See John E. Crowley, The Privileges of Independence: Neomercantilism and the American Revolution (Baltimore, 1993), for characterization of Sheffield as a neomercantilist. 
trade restrictions on Britain's former colonies. Given that Lord Sheffield wrote from a distinctly partisan and a not wholly informed point of view, and given the ready rebuttals of his gloomy predictions by Tench Coxe and Thomas Paine among others, it is surprising that Anglo-American historians and economists have so long privileged his calculations and forecasts. ${ }^{19}$ When examined from a broader Atlantic perspective, however, Lord Sheffield's views are challenged and rendered to some degree irrelevant.

\section{Spanish Observations from America}

Contemporary Spanish sources recount a story that is markedly different from Sheffield's version of early American commercial prospects. During the very same months in 1782 and 1783 that Sheffield penned his Observations in faraway London, the Spaniard Francisco Rendón was at work on the scene in Philadelphia, preparing two memoranda for his superiors in Madrid on the finances and foreign trade of the new United States. ${ }^{20}$ By then, this career bureaucrat had resided in the American port for nearly five years, first as personal secretary to Charles III's original "observer" to the Continental Congress, Juan de Miralles, then as the ranking Spanish observer in the United States in his own right. Before his untimely death on April 28, 1780, at George Washington's headquarters in Morristown, Miralles, operating openly as a provisions merchant and clandestinely as a spy, had cultivated the American political establishment and sent vital intelligence to Madrid. He also shipped mid-Atlantic flour to feed Spanish troops stationed in Cuba. Following Miralles's death, Rendón, formerly posted in Havana itself, continued to oversee and shape the expanding trade between the

${ }^{19}$ Jacob E. Cooke, Tench Coxe and the Early Republic (Chapel Hill, 1978). Coxe's rebuttal, A Brief Examination of Lord Sheffield's Observations on the Commerce of the United States, was printed in six installments in the American Museum from March through July of 1791 and was subsequently published in pamphlet form. Also see Thomas Paine, "A Supernumerary Crisis, December 9, 1783," in Charles J. Norman, ed., The Crisis Papers, 1776-1783, by Thomas Paine (Albany, N.Y., 1990), 182-85. A number of West Indian planters, traders, and colonial officials also refuted Sheffield's arguments; for one example, see Edward Long, A free and candid Review of a Tract, entitled "Observations on the Commerce of the American States," showing the pernicious consequences, both to Great Britain, and to the British Sugar Islands, of the Systems recommended in that Tract (London, 1784), Goldsmith'sKress Library of Economic Literature, reel no. 1276, book no. 12628.15.

${ }^{20}$ Francisco Rendón, "Memoria sobre las fianzas de los Treze Estados Unidos de América Septentrional," 20 Apr. 1782; and "Primera y Segunda parte de la memoria sobre las produciones exportaciones e Ymportaciones y modo de hacer el comercio con los Estados Unidos: Que Don Francisco Rendón remite al Exmo Señor Don J. de Gálvez," 8 Sept. 1783, Archivo General de Indias, Seville (hereafter AGI), Santo Domingo (hereafter SD), legajo (hereafter leg.) 2597. The original bundle of documents has been microfilmed, and photocopies are available from the Tulane University Library. 

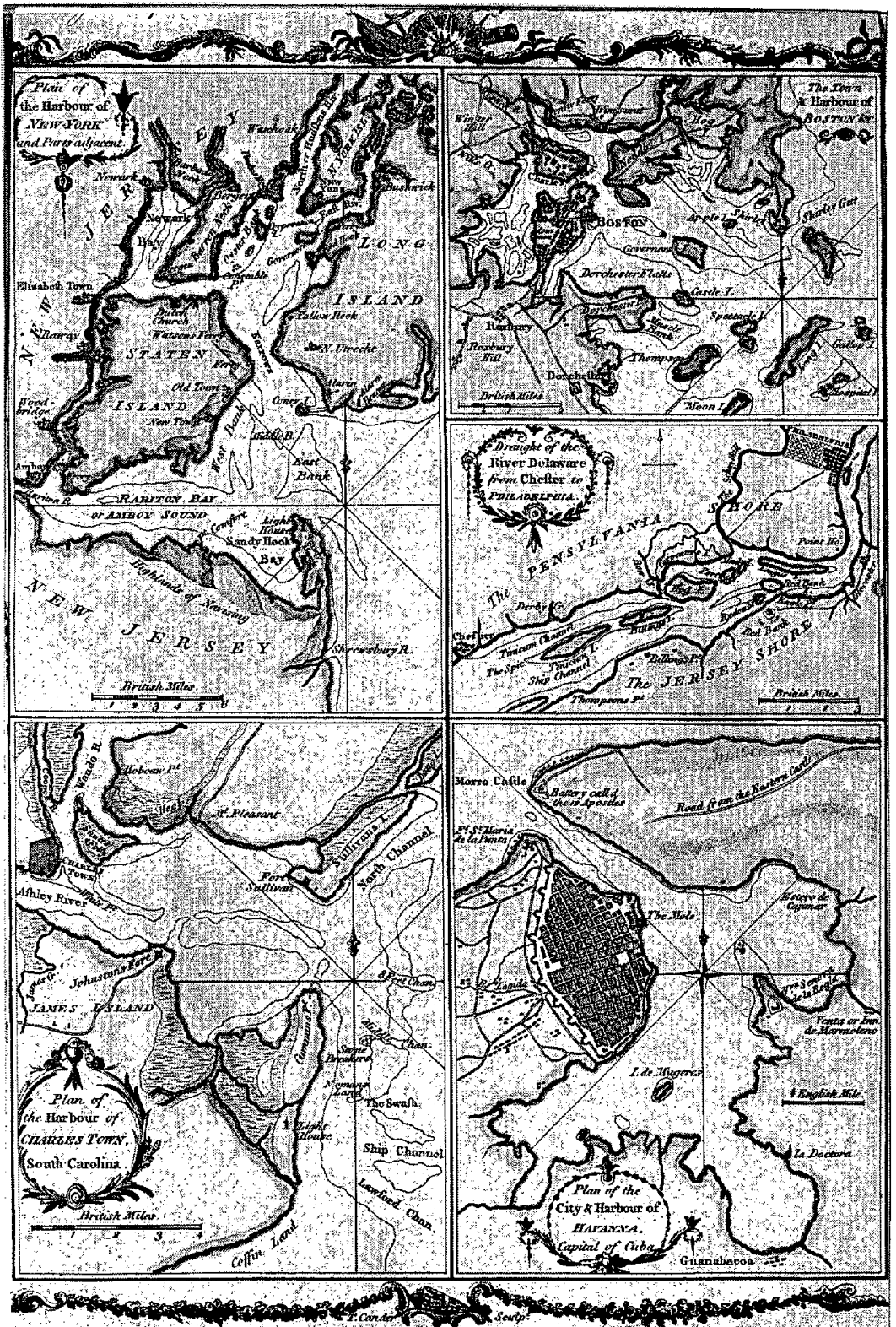

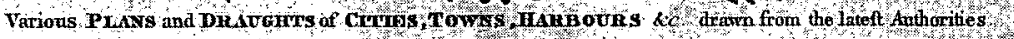

Various plans and drafts of cities, towns, and harbors drawn from the harbors of Havana, Charlestown, New York, Philadelphia, Boston, ca. 1782. Courtesy of The Library Company of Philadelphia. Although the cartographer is unknown, the inclusion of Havana suggests the importance of trading connections between the Spanish colony and the North American mainland in the era of the American Revolution. 
American revolutionaries and the Spanish colony. This day-to-day, nutsand-bolts experience offered Rendón plenty of opportunity for contact with Robert Morris and other merchants anxious to sell U.S. produce to non-British West Indian consumers. Not only did Rendón and Morris serve as joint executors of Miralles's estate; they also collaborated in developing a "commercial operation that became a major source of food for Cuba" and the source of considerable profits for most participants. ${ }^{21}$

Such direct and frequent access to high-ranking U.S. officials provided Rendón with privileged sources of information for his memoranda regarding the economic prospects of the thirteen states. He was not a patsy of the American leaders, however. In addition to congressional records, Rendón also utilized reports from foreign merchants trading in Philadelphia and enjoyed a solid working relationship with the French envoy. Moreover, Rendón consciously strove for impartiality in his interpretations and was said to lack the "magic ingredient" for full acceptance at the Congress-that is, sufficient enthusiasm for the American cause. ${ }^{22}$ Unlike Lord Sheffield's, then, Rendón's observations were current, first-hand, and not overtly partisan.

It is the second part of Rendón's second memorandum that offers the most pertinent insights into the prospects for American commerce. Here it is his primary contention that "England still does not perceive the extent of its loss." Ironically, Rendón quoted one of Lord Sheffield's political opponents, the aforementioned Earl of Shelburne, who commented that "the sun of Great Britain set with the independence of America." ${ }^{23}$ Rendón appeared to be very familiar with the factions within the British House of Commons, alluding to [William Pitt the Younger] the Earl of Chatham's estimates of the profits of colonial trade at one point and refuting those in Commons who argued that the English and Americans were still a single people. Still, Rendón did concede that Great Britain might enjoy preference in the trade of the United States for several reasons: prior French attempts to unload shoddy merchandise, mainly inferior textiles, on the American market; the persistent shortage of specie in the United States; and the fiscal and commercial regulations of other European powers that formed significant obstacles

\footnotetext{
${ }^{21}$ Cummins, Spanish Observers, esp. 174 and 180 . Also see Josep M. Bernades, Els catalans a les Índies (1493-183o), vol. 1 (Barcelona, 1992), 287-89, for a recent biographical sketch of Miralles.

${ }^{22}$ Cummins, Spanish Observers, 170.

${ }^{23}$ In addition to the original Spanish source utilized above, there exists a typescript of an English translation of Rendón's second memorial in the Aileen Moore Topping Translations, Manuscript Division, Library of Congress, of which John McCusker supplied a copy. See Cummins, Spanish Observers, p. 211, for a brief explanation of the dimensions of Topping's project. My own translation agrees closely with hers; there are no original page numbers to cite in either the Spanish or English versions.
} 
to U.S. trade. More concretely and practically, Rendón suggested that the French could supplant the American demand for Portuguese wines other than Madeira if the price were right. He also predicted that, after France, Holland would have the greatest trade with the United States, since the Dutch seemed to anticipate demand very shrewdly. Of late, they had shipped variegated cargoes, including "skates, which are a kind of go-cart with which they run over ice. This proves how much attention they devote to providing necessities to the people with whom they trade."

In a straightforward, nonobsequious tone that rarely characterizes the writings of Spanish imperial bureaucrats to their superiors, Rendón pointed out that Spain was not presently able to compete with England, France, and Holland in trading with the United States. There were not enough factories on the peninsula to enable Spain "to match their industries." However, Rendón believed that Spain could capture some of the American market for superfine woolen cloth, due to the inherent superiority of the Spanish product and to the fact that, "despite the excessive heat experienced here from May until mid-September one rarely sees a suit not made of wool." He thought that Spain might also be able to capture some of the trade in wines, sugars, oils, fruits, some silks, and counterpanes. Moreover, he recommended that a network of consuls and Spanish traders on the scene would boost American confidence in peninsular products. It is worth noting that the system Rendón envisioned was in place by the time Consul General Valentín Foronda arrived on the U.S. mainland in 1802. Rendón also drew explicit attention to the lands west of the Appalachians as a potential market for Spanish exports. Issues pertaining to the navigation of the Mississippi River, of course, soon became the more closely studied focus of diplomatic negotiations between the two nations.

Beyond this tempered and candid assessment of Spain's prospects for trade with the United States, Rendón made some more general predictions in 1783. Canada, he thought, would prove unprofitable and expensive for the British. And, unlike Lord Sheffield, he cautioned that although Americans were debtors, the "prodigious production" of their lands enabled them to meet their obligations. Two centuries later, Javier Cuenca Esteban's painstaking calculations unwittingly proved that Rendón's predictions were right on the mark: in essence, the United States was able to pay for its British imports in the 1790 and early 1800 by making its balances on trade with the Spanish Empire. ${ }^{24}$

From his vantage point in Philadelphia, Rendón actually worried that the British government would be farsighted enough to grant

${ }^{24}$ Cuenca Esteban, "Trends and Cycles," 521-41. 
concessions to the Americans in order to attract their confidence. In particular, the Spanish observer feared that Americans. would be free to trade with the British Caribbean islands as part of a strategy to cement trade ties between the former colonies and their metropolis at the expense of the other European powers. Therefore, in contrast to Lord Sheffield's defensive, if not punitive reaction, Rendón's logic dictated that Great Britain respond to postwar imperatives in an innovative, distinctly nonmercantilist way. Yet this was not to be. Indeed, the collective mentality of British policymakers in the 1780 s puts one in mind of the inability to "think triumphantly" that had plagued their predecessors once the tide turned toward victory in the Seven Years' War some two decades earlier. ${ }^{25}$

Rendón closed his second memorial by reporting that his contacts in Philadelphia and New York "insist with the greatest tenacity that it is in the interests of the European Powers to grant to the United States free trade with the islands." To underscore this point, he also forwarded to his superiors in Madrid a letter written by an American politician and trader, who may have been Robert Morris. ${ }^{26}$ This letter argued in the strongest possible terms for the full opening of the Spanish islands, particularly Cuba, to U.S. trade. Although Rendón carefully recorded that he found some of the arguments advanced to be "specious to say the least" and "too delicate for me to form an opinion," he nevertheless transmitted the document to the Spanish court, ostensibly in the process of determining whether or not to allow continued American access to Cuba. While he and the U.S. merchants involved awaited the decision from Madrid, Rendón continued to issue the necessary permits to allow Philadelphia ships to sail for Havana, even as some imperial bureaucrats there, operating under different imperatives, tried in vain to minimize contact.

These actions suggest that Rendón actually entertained the possibility that Spain would not revert to traditional mercantilist policies and close the Cuban trade to U.S. shippers after the peace treaty was signed. The American letter writer had insisted "that if Spain would permit the free introduction of American Products into its islands, such would be the abundance which would reign in them that her planters would be able to dedicate all their work and attention to the improvement of

\footnotetext{
${ }^{25}$ See John M. Murrin, "The French and Indian War, the American Revolution, and the Counterfactual Hypothesis: Reflections on Lawrence Henry Gipson and John Shy," Reviews in American History 1 (Sept. 1973): 307-18, for the backward-looking mentality of the British ministers after the great victory over France.

${ }^{26}$ Nuxoll and Gallagher, eds., The Papers of Robert Morris, vol. 8, pp. 467-79, for a printed Spanish version of the letter and an English translation of the same, preceded by a learned and lengthy annotation that explores the question of authorship. Special thanks go to Betty Nuxoll for clarifying some points about this document.
} 
their Plantations, by which means they would quickly enrich themselves and consequently they would enrich the Nation to which they belong."

Yet this classic formulation of the theory of comparative advantage grafted onto a more familiar mercantilist rationale did not persuade peninsular decision-makers. Despite detailed calculations regarding the yields of sugar and wheat, respectively, and despite repeated insistence that the British islands had prospered before the Revolution only because of their trade with the mainland, the pleas of the letter writer went unheeded. As most American historians are quick to point out, Spain reimposed the prohibition on direct trade between the United States and the Spanish West Indies in $1784 .{ }^{27}$

Was there any real possibility that Spain might have acceded to these requests emanating from Philadelphia? If so, hope was undoubtedly dashed once Great Britain-to Rendón's professed surpriserestricted American access to the British West Indies. News of this British decision reached Philadelphia soon after Rendón had completed his memorial. Nevertheless, he transmitted it and the American letter intact to Spain. These forward-looking arguments probably did not arrive in time to influence significantly the higher levels of Spanish imperial administration. Moreover, the Spanish observer undermined his own credibility by engaging in an amorous relationship that became increasingly public around this time. Rendón shocked proper Philadelphians by living openly with Margarite Marshall, a woman from an American family lacking both commercial success and social status. Of even greater concern to the Spanish crown was the fact that Miss Marshall was a Protestant, and thus an unsuitable candidate for marriage to a rising imperial bureaucrat. Rendón nearly wrecked his career with this scandalous liaison. His petition to marry her languished, and he was demoted to secretary of the legation once Diego de Gardoqui arrived as Spain's first fully accredited representative in Philadelphia. Rendón was supposed to assist Gardoqui, but the two did not work well together. To avoid further embarrassment, Rendón was recalled to Madrid in 1786 . Once there, he renounced his true love, who was waiting patiently in Philadelphia to join him at his next post. His career back on track, Rendón then was named the intendant of Louisiana. ${ }^{28}$

Most early Americanists recognize the name of Diego de Gardoqui, who was from a prominent merchant family in Bilbao and had previously

\footnotetext{
${ }^{27}$ The immediate situation is carefully reconstructed by James A. Lewis, "Anglo-American Entrepreneurs and the Significance of the Expulsion of 1784-1785," in Barbier and. Kuethe, eds., The North American Role, 112-26, 210-14.

${ }^{28}$ Cummins, pp. 192-95, summarizes the scandal, which was the subject of numerous pieces of correspondence in several of the legajos I have consulted in Spain. Miguel Gómez del Campillo, Relaciones diplomáticas entre España y los Estados Unidos (Madrid, 1944), $\mathrm{xix}-\mathrm{xxi}$, maintains that Gardoqui himself argued strongly against the marriage.
} 
managed Spain's consular service in London. They associate him with the diplomatic negotiations surrounding navigation of the Mississippi River. What many have not realized, however, is that his two assistants, Josef de Jáudenes and José Ignacio de Viar, spent much of their time during the 1790 s in Philadelphia, overseeing a revived trade between the United States and Cuba. In other words, since Revolutionary and early national historiographies conventionally break around 1789 or 179o, Americanists often fail to recognize that the Spanish trade ban imposed in 1784 was short lived. In fact, by 1789 Bourbon restrictions had already been modified to permit direct trade between the United States and Cuba under certain circumstances. ${ }^{29}$ It was a surprisingly quick recognition of economic imperatives on the island. And, by the end of the next decade, thanks to the Napoleonic Wars, most formal commercial regulations were unenforceable in any event. The United States-Cuba trade of which Robert Morris and Francisco Rendón had dreamed quickly came to fruition as sugar production on the French island of San Domingue plummeted, Spanish metropolitan shipping to its colonies slowed to a trickle, and the British verged on starving their own sugar islands by denying them access to American provisions. ${ }^{3^{0}}$ In short, Lord Sheffield's scenario had been rendered obsolete.

By the first decade of the nineteenth century, transatlantic realities continued to dim prospects for those with a mercantilist, and even a neomercantilist, bent. Valentín Foronda, the Spanish consul general who was stationed in Philadelphia between 1802 and 1807 , recognized full well how U.S. merchants were already able to exploit the most dynamic market in the Caribbean, namely Cuba, the one that Lord Sheffield and many early national historians have overlooked. As the skeptical but obedient product of one imperial system and a shrewd admirer of the other, Foronda was uniquely positioned to observe the increasingly divergent legacies of Spanish and British colonialism.

\footnotetext{
${ }^{29}$ L. K. Salvucci, "Anglo-American Merchants and Stratagems for Success"; Michael A. Otero, "The American Mission of Diego de Gardoqui, 1785-1789" (Ph. D. diss., UCLA, 1948); and José Antonio Armillas, "Viar y Jáudenes," in [no editor] Suma de Estudios Homenaje a Dr. Canellas (Zaragoza, 1969), 51-76. Some of the trading permits that Jáudenes and Viar issued are preserved in the AGI, Papeles de Cuba, leg. 1469, a portion of which has been photocopied and is held at the Library of Congress.

${ }^{30}$ Emphasis upon the British starving their own islands is mine, but see Seymour Drescher, Econocide: British Slavery in the Era of Abolition (Pittsburgh, 1977). The dating of the decline of the British West Indies is the subject of considerable scholarly debate. For two conflicting interpretations, see Selwyn H. H. Carrington, "The American Revolution and the British West Indies' Economy," in Barbara L. Solow and Stanley L. Engerman, eds., British Capitalism and Caribbean Slavery: The Legacy of Eric Williams (Cambridge, 1987), 13562; and John J. McCusker, "Growth, Stagnation, or Decline? The Economy of the British West Indies, 1763-1790," in Hoffman et al., eds., The Economy of Early America, 275-302.
} 
On Christmas Eve of 1803 , Foronda wrote to his superiors in Spain: "As I've observed before, the ports with true trading privileges are not in Spain but rather here; and it appears that citizens of the United States hold exclusive trading rights with Cuba." ${ }^{11}$ This was hardly the intended result of nearly fifty years of Bourbon commercial reforms that were designed to modernize Spanish mercantilism, moving toward "freer trade" while still retaining privileges and profits within the empire. In this specific instance, "neomercantilist" is an apt characterization of the sentiments. As a realist, even Foronda conceded that some direct trade between the United States and Spain's prized Caribbean colony had to be tolerated; otherwise, Cuban sugar production, not to mention crown revenues, would falter. In a comparative vein, it should be emphasized that this was a point most British policymakers apparently failed to grasp with regard to production on their own sugar islands. However, as the king's vigilant servant, Foronda maintained that such direct trade must be taxed; at the very least, he argued, American cargoes should be carried in Spanish ships so that some gains accrued to Spain. To this end, his expanded network of Spanish consuls along the eastern seaboard was supposed to control traffic by selling shipping permits. But instead of purchasing them, Philadelphia ship captains had grown so bold that they would "come by to bid me farewell and ask if I wished to send some letters along with them." As Foronda himself recorded, he could only lower his head, shrug his shoulders, and pray silently that the king would recognize his faithful service. ${ }^{32}$ Some fifteen months later, the conscientious Basque catalogued a similar set of abuses perpetrated by the Philadelphia merchants; with a trace of resignation this time, he noted that it was like "preaching in the desert." But still he did not give up. With a certain degree of irony, he vowed in April of 1805 to withstand, "like the Rock of Gibraltar," yet another wave of American affronts. ${ }^{33}$ Thus did Valentín Foronda try to

\footnotetext{
${ }^{31}$ Valentín Foronda (hereafter VF) to Pedro de Ceballos (hereafter PC), Phila., 24 Dec. 1803, Archivo Histórico Nacional, Madrid (hereafter AHN), Estado, leg. 6175 bis. Foronda estimated that at least fourteen American ships then were in Havana harbor, and more were arriving daily. He had voiced similar complaints some nine months earlier: VF to PC, Phila., 7 Apr. 1803; AGI, Indiferente General (hereafter IG), leg. 1604. Little had changed after two more years: VF to PC, Phila., 8 May 1805, AHN, Estado, leg. 6175 bis.

${ }^{32}$ VF to PC, Phila., 24 Dec. 1803 , AHN, Estado, leg. 6175 bis. The consul general also complained that ship captains frequently advertised impending departures in the local newspapers and then left for Havana without consulting him: VF to Miguel Cayetano Soler (hereafter MCS), Phila., 28 Mar. 1802, AHN, Estado, leg. 6175.

${ }^{33}$ VF to PC, Phila., 25 Jan. and 20 Apr. 1805, AHN, Estado, leg. 6175 bis. Examples of Foronda's frustration and siege mentality abound in the correspondence: VF to PC, Phila., 3 Mar. and 8 Sept. 1803, AHN, Estado, leg. 6175 bis; VF to PC, Phila., 29 Mar. 1803, AGI, IG, leg. 1604 .
} 
defend Spanish interest with a zeal that alternately amused and irritated even his fellow imperial bureaucrats. ${ }^{34}$

Ridiculed in the streets by determined shippers and baited in the Philadelphia press by anti-Spanish publishers, Foronda enjoyed little popularity for discharging his consular duties. ${ }^{35} \mathrm{He}$ did not realize, or quite probably did not care, how markedly his approach differed from that of his predecessors in the late 1790 . Spanish diplomats such as Gardoqui, Jáudenes, and Carlos Martínez de Irujo had cut dashing, or at least convivial, figures on the New York and Philadelphia social scenes. They entertained and were entertained by prominent American merchants and politicians. They befriended and even married into distinguished regional trading and political families, including the Stoughtons and the McKeans. They took but sporadic note of widespread infractions of Bourbon commercial regulations, preferring instead to use their licensing powers to advance the fortunes of their favorites. Sometimes, they went so far as to strike their own business deals with American partners. ${ }^{36}$ The gulf between metropolitan policies and local enforcement was thus very wide in Spanish imperial interactions.

Foronda, in vivid contrast to these earlier Spanish officials in residence, was a self-admitted workaholic and an elitist man of letters. By his own admission, he did not regularly travel by coach, and he "never went to teas or dances." Apparently, his grasp of spoken English was tenuous, although his son Fausto, the vice-consul, was fluent. Together they lived a quiet life in Philadelphia. In addition to completing routine paperwork, they read at least three regional newspapers daily, translated numerous official speeches and tracts for their peninsular superiors, and authored several scholarly papers. Valentín Foronda cemented his relationships with men like Thomas Jefferson not with rounds of drinks at City Tavern, but rather through learned exchanges within the more intimate confines of the American Philosophical Society. ${ }^{37}$ Foronda

34 “. ... and contrary to custom, [Foronda] is extremely succinct in this matter": [?] to Carlos Martínez de Irujo, later the Marqués de Casa Irujo (hereafter CMI), Aranjuez, 28 Jan. 1806, AHN, Estado, leg. 6175 bis. Foronda repeatedly complained that higher-ranking Spanish officials refused to reply to his letters and improperly administered commercial laws: VF to PC, Phila., 20 Apr. 1803, AGI, IG, leg. 1604; copies of letters sent by VF to the intendant of Cuba, Phila., 16 Nov. and 20 Dec. 1803, AHN, Estada, leg., 6175 bis.

${ }^{35}$ VF to PC, Phila., 8 Sept., 8 Nov., and 24 Dec. 1803 , AHN, Estado, leg. 6175 bis; the first letter relates how American shippers tried to force him to fill out certificates of good health for crews during an outbreak of yellow fever in the city. For libelous attacks upon the Spanish royal family in the local press, see VF to PC, Phila., 8 and 15 May 1805, AHN, Estado, leg. 6175 bis.

${ }^{36}$ Irujo formed a business partnership with James Barry in 1797; CMI to Santa Clara, Phila., 13 Feb. 1797, AGI, México, leg. 2486. To Foronda's great consternation, Irujo was also involved with John Craig, one of the most prominent merchants in Philadelphia: VF to MCS, Phila., 16 June and 21 July 1806, AGI, IG, leg. 1603.

${ }^{37}$ J. R. Spell, "An Illustrious Spaniard in Philadelphia, Valentín de Foronda," Hispanic Review 4, no. 2 (1936): 136-40; Robert S. Smith, "Valentín de Foronda, diplomático y 
also vigorously defended Spain when men on the street, be they aging McKeans or nameless mariners, crossed his path. ${ }^{38}$ Most important, to the best of his ability, he always tried to enforce both the letter and the spirit of Bourbon law in matters relating to commerce between America and the Spanish Empire. In so doing, Foronda clashed with Philadelphians and their Spanish collaborators who for years had profited from trading ventures, legal and otherwise. ${ }^{39}$

The feisty Basque may have put himself in a difficult position, but he was hardly a pathetic figure. Rather, Foronda was a perceptive and widely read political economist, far more so than Lord Sheffield. Like many educated men of his age, Foronda was profoundly influenced by the French physiocrats and by Adam Smith (whose Wealth of Nations, incidentally, was first translated into Spanish by Irujo, who, like Gardoqui, had been posted in London prior to his American appointment). To those who dealt with him in Philadelphia, the fact that Foronda came under suspicion in Spain for his "modern" views after the Bourbon restoration of 1814 might have seemed inconceivable. His published works were censored, and he died a broken man in 1823. Eventually, however, his reputation was rehabilitated, and he now enjoys considerable fame in the world of Hispanic letters. ${ }^{40}$

economista," Revista de Economía Política 10, no. 2 (1959): 425-64, esp. 429. VF to PC, Phila., 14 Feb. 1807, AHN , Estado, leg. 6175 for "no voy a los tés ni a los Bailes," as well as the observation that "los papeles públicos cuentan todo. .."; Fausto de Foronda to PC, Phila., 17 and 24 Oct. 1803 , AHN, Estado, leg. 6175 bis. Fausto was later sent to Baltimore to replace the consul there: VF to PC, Phila., 26 Mar. 1805 , AHN, Estado, leg. 6175 bis.

Foronda was elected a full member of the American Philosophical Society on 16 July 1802; he immediately presented to that body several of his published treatises. Josef de Jáudenes had been elected in 1796, but he does not appear to have been very active or prolific: American Philosophical Society membership file and general catalogue, Philadelphia. A published source claims that Irujo was also a member: Sandra Sealove, "The Founding Fathers as Seen by the Marqués de Casa-Irujo," Americas 20 (1963): 37-42. On one occasion, Foronda complained of the "pequeño número de Económico-políticos y de literatos que se encuentran aquí"; the rest of the time, however, he seemed quite happy with his intellectual contacts: VF to PC, Phila., 30 Apr. 1803 , AHN, Estado, leg. 6175 bis.

${ }^{38}$ VF to [?]. Phila., 20 July 1802 , AHN, Estado, leg. 6175; VF to PC, Phila., 5 Apr. and 8 Sept. 1803 , AHN, Estado, leg. 6175 bis. It is unclear which McKean Foronda confronted; Irujo had married into that family in 1796. See Eric Beerman, "Spanish Envoy to the United States: Marqués de Casa Irujo and His Philadelphia Wife Sally McKean," Americas 37 (1981): $445-56$.

${ }^{39}$ For over twenty years, John Leamy, a well-connected Irish Catholic merchant who settled in Philadelphia after 1780 , had virtual carte blanche to trade with Spanish imperial ports. Once Foronda arrived on the scene, however, Leamy began to experience unprecedented difficulties. The consul general's long-simmering quarrel with Irujo came to a head over the latter's support of Leamy, who was Jáudenes's landlord, in 1806: VF to PC, Phila., 14 Jan. 1803, AHN, Estado, leg. 6175 bis: CMI to [?], Phila., 28 Mar. 1806, AGI, IG, leg. 1603.

${ }^{40}$ Smith, "Valentín de Foronda," 428-38; Marcelo Bitar Letayf, Economistas españoles del siglo XVIII: sus ideas sobre la libertad del comercio con Indias (Madrid, 1968), 158-63; Robert J. Shafer, The Economic Societies in the Spanish World (1763-1821) (Syracuse, 1958), 12-13, 40; Richard Herr, The Eighteenth Century Revolution in Spain (Princeton, 
Many of Foronda's writings professed great admiration for the economic progress of the United States. In his 1804 treatise on the subject, the consul general acknowledged that his host nation could easily outsupply Spain with foodstuffs, thanks to the richness of its soil. ${ }^{41}$ In fact, Foronda repeatedly emphasized the industrious cultivation of its fertile lands as the foundation of U.S. prosperity. And while he had little respect for the military abilities of "these Republicans," he often attested to their skill as merchants, if not to their preoccupation with making money. As for the North American merchant marine, Foronda concluded, in a vein reminiscent of Adam Smith's passage about the superior value of the physical capital of the Tartars compared with the silver assets of the Spanish kings: "Ten thousand vessels upon the seas-in truth, this is a wealth greater than the famous mountains of Potosi.." ${ }^{2}$ From his practical experiences in regulating trade from Philadelphia, then, Foronda pronounced the Jeffersonian emphasis upon an agriculturally based foreign trade to be both proper and profitable. Thus, although Foronda did not fit easily into the social world of Philadelphia, he clearly shared much of the mind-set of the newly triumphant political party. ${ }^{43}$

1958), 55; and, more recently, José Manuel Barrenechea, "Valentín de Foronda ante la fisiocracia," in Ernest Lluch y Lluis Argemi I D'Abadal, eds., Agronomía y fisiocracia en España (1750-1820) (Valencia, 1985), 153-83, which, interestingly enough, downplays the impact of Foronda's North American experiences on his thinking.

${ }^{41}$ Valentín de Foronda, "Apuntos ligeros sobre los Estados Unidos de la América Septentrional," Phila., 13 Mar. 1804, MSS., Obadiah Rich Collection, New York Public Library. A printed version is available in José de Onís, ed., "Valentin de Foronda's Memoir on the United States of North America, 1804," Americas 4 (Jan. 1948): 351-87.

Foronda authored another piece in which he urged the King to relinquish some of his vast, but unproductive empire. The short-sighted ones, in Foronda's opinion, were those who believed it better for Spain to possess territory thousands of leagues far away than to cultivate its own rich soil, which would produce more than all of America if cared for properly: VF to PC, Phila., 20 Apr. 1803, AHN, Estado, leg. 6175 bis.

42 "Aquí hay muchos soldados en el nombre, pero sin disciplina ... no hay obediencia, no hay respecto a los Jefes": VF to PC, Phila,, 5 Aug. 1805, AHN, Estado, leg. 6175 bis. "Sólo piensan en ganar Dólares": VF to PC, Phila., 24 Jan. 1806, AHN, Estado, leg. 6175. Sealove, "The Founding Fathers," 37, quotes Irujo as observing that "money is the God of the Americans." Some seven years later, Foronda wrote: "el Oro es el Dios a quien rinden adoraciones." VF to [?], Phila., 24 Jan. 1803, AHN, Estado, leg. 6175 bis. Also see Edwin Cannan, ed., Adam Smith: An Inquiry into the Nature and Causes of the Wealth of Nations ([1776], 1904, Chicago, rep. 1977), 450-51: "Wealth, therefore, according to them [the Tartars], consisted in cattle, as according to the Spaniards, it consisted in gold and silver. Of the two, the Tartar notion, perhaps, was nearest to the truth."

${ }^{43}$ The Jeffersonian view is ably sketched out in Drew R. McCoy, The Elusive Republic: Political Economy in Jeffersonian America (Chapel Hill, 1980); even more germane to this study is Joyce Appleby, "What is Still American in the Political Philosophy of Thomas Jefferson?" William and Mary Quarterly, 3rd ser., 39 (1982): 287-309.

Foronda was delighted to report Jefferson's reelection to his superiors: VF to PC, Phila., 13 Jan. 1805 , AHN, Estado, leg. 6175 bis. Irujo also closely identified with the Jeffersonians: Sealove, "The Founding Fathers," 38-39. Moreover, the consul general probably attended services at Old St. Mary's Roman Catholic Church in Philadelphia, where many prominent Republicans worshipped. 
What disturbed Foronda profoundly, however, was a phenomenon understood by some of the new officeholders but usually overlooked in the historiography of early national America. Not only was an entrepôt like Havana the perfect market in theoretical terms for the new nation, since it required mainly foodstuffs and agricultural implements, rather than corruption-inducing manufactured goods. But the consul general's own carefully gathered statistics also demonstrated that early American commercial success occurred at the expense of Spain. It was bad enough that the metropolis itself imported grains worth millions of reales de vellón annually from the United States. ${ }^{44}$ Even more horrifying to the good Spanish legalist was the extent to which Americans had penetrated Bourbon colonial markets. During the first decades of the nineteenth century, Cuba was fast becoming the richest colony in the world; yet the United States, not Spain, appeared to reap the greatest benefits. If one theme predominated in Foronda's official correspondence, it was the nearly total absorption of profits from Cuba by American merchants. ${ }^{45}$ Galled by negative references to Spain in the local press in August of 1805, Foronda wondered, "If Spanish imperial ports were closed to them, where would they send their agricultural products, which represent all of their wealth?" 46 Indeed, this was a telling point. Yet he need not have worried that the U.S. trade with Spain went unappreciated in the United States. Bluntly arguing against a possible war with Spain, a contemporary writer from the Richmond Inquirer observed that American exports to Spain had exceeded those to any other country in $\mathbf{1 8 0 3 .}$ Moreover, he continued, without trade to the Spanish Caribbean and South America, "a considerable quantity of provisions and lumber would thus remain in our magazines without any profit, at the same time we should be shut out from the principal markets in which we obtain our real circulating medium." Like Foronda, this unidentified writer from Virginia recognized that American prosperity depended in no small part upon the Spanish Caribbean demand for U.S. foodstuffs and the corresponding supply of Spanish American specie that flowed up through Cuba. ${ }^{47}$

\footnotetext{
${ }^{44}$ VF to PC, Phila., Jan. 25, 1805, AHN, Estado, leg. 6175 bis, wherein he lamented the lost opportunity to spend these funds on internal improvements in Spain, such as canals.

${ }^{45}$ Susan Schroeder, Cuba: $A$ Handbook of Historical Statistics (Boston, 1982), 3; VF to PC, Phila., 7 Apr. 1803, AGI, IG, leg. 1604.

${ }^{46}$ VF to PC, Phila., 5 Aug. 1805 , AHN, Estado, leg. 6175 bis.

${ }^{47}$ VF to PC, Phila., 2 Nov. 1804, AHN, Estado, leg. 6175, in which the consul general included the previous day's issue of the Philadelphia Gazette and Daily Advertiser that contained a reprint of the undated article from Richmond. Spanish American revolutionaries also appreciated this point: see Manuel Torres, An Exposition of the Commerce of Spanish America with Some Observations upon Its Importance (Phila., 1816), esp. 13-14.

Foronda not only pinpointed Mexico and Peru as the predominant sources of specie for the United States; he also specifically tied specie supply trends to annual levels of activity in the American trade to the East Indies: VF to PC, Phila., 7 Apr. 1803, AGI, IG, leg. 1604; VF to PC, Phila., 25 Jan. 1805, AHN, Estado, leg. 6175 bis.
} 
Foronda's observations raise an interesting issue. How had the United States, barely rid of its own colonial status, managed to gain control of another empire's most lucrative colonial trade? Because he arrived on the scene too late to witness its origins, Foronda never posed this question directly. But his five-year catalog of U.S. commercial abuses does address the issue of how Americans habitually took advantage of problems of shipping and supply throughout the Spanish Empire. With nearby and remote ports alike, a "scandalous" contraband continued to flourish. Foronda kept partial track of some specific cases, but he never provided any overall estimates. ${ }^{48}$ Instead, he focused upon a few loopholes that vigilant Spanish bureaucrats could close without difficulty. Writing on this occasion with the outrage of a more traditional mercantilist, Foronda provided a series of recommendations that show subsequent historians the extent of U.S. commercial involvement with Cuba.

According to the consul general, Cuban officials should stop the admission of American vessels that did not carry authentic licenses from him and his vice-consuls stationed in the larger U.S. ports. Forgers had become so careless that Spanish proper names were hilariously misspelled; thus, they were easily identifiable. ${ }^{49}$ Americans must also be discouraged from sailing indirect routes to Cuba, ending their practice of departing from smaller U.S. ports where no consuls resided or from ports of a third nation. ${ }^{50}$ Unlicensed arrivals, even in cases of shipwreck, which were often staged to gain entrance into ports, had to be turned firmly away. ${ }^{11}$ When admitted, vessels should be searched thoroughly for concealed goods. All permitted products should enter only after paying the requisite taxes. Ships should not be dispatched to the

${ }^{48}$ Almost every time that Foronda mentioned contraband, the word "escandoloso" preceded it. Following the Louisiana Purchase, he predicted that New Orleans would be the focus of contraband for the entire Gulf of Mexico: VF to PC, Phila., 24 Oct. 1803, AHN, Estado, leg., 6175 bis. Foronda also was concerned with attempts, often by New Englanders on whaling expeditions to the South Atlantic or the northwest coast of America, to penetrate Peruvian and Chilean markets. After calculating the amount of declared cargo against the capacity of a specific ship's hold, he asked: "So are they carrying 1635 tons of air?": VF to PC, Phila., 20 Aug. 1805, AHN, Estado, leg, 6175 bis.

${ }^{49}$ One letter in particular lists many of these loopholes: VF to PC, Phila., 3 Jan. 1803 , AGI, IG, leg. 1604. Four months later, the consul general sarcastically enumerated them again and pointed out the obvious forgeries: VF to PC, Phila., 20 Apr. 1803, AGI, IG, leg. 1604.

${ }^{50}$ Foronda was especially incensed over ships that cleared for the Floridas and then went on to Cuba: VF to MCS, Phila., 20 May 1803; VF to PC, Phila., 20 May and 23 July 1803 , AHN, Estado, leg. 6175 bis. For evidence of indirect trade via the Caribbean islands of other European powers, see Carmelo Richard Arena, "Philadelphia-Spanish New Orleans Trade: 1789-1803" (Ph. D. diss., University of Pennsylvania, 1959).

${ }^{51}$ The consul general maintained that most shipwrecks were staged to gain entry to the Cuban ports. In cases when damaged ships were admitted, he recommended that, instead of allowing repairs to be financed by sales of cargoes, the vessels themselves should be sold at public auction: VF to PC, Phila., 23 Jun. 1803, AHN, Estado, leg. 6175 bis. 
United States for needed supplies (breadstuffs, horses, wooden containers for shipping sugar) except in emergencies, and then only under the most circumscribed conditions; the same ships should be readmitted with the authorized cargoes solely. Foreigners who took advantage of a royal policy that allowed them to sell extra flour in return for supplying Cuba with slaves were not to be granted this concession merely for picking up a few unfortunate blacks on neighboring islands..$^{52}$ As much traffic as possible should be carried by Spanish-owned vessels manned by crews that were at least three-quarters Spanish. Tax incentives to build up the Spanish merchant marine through the purchase of American ships had not been effective and thus needed to be revised. Those Americans and Spaniards who repeatedly transferred ownership of the same vessels back and forth should be stiffly taxed and/or fined. ${ }^{53}$ And finally, according to Foronda, Spain should negotiate greater powers for its consuls stationed abroad. As the situation stood in 1803 , Spanish diplomats had virtually no legal recourse in the United States, nor did they have any powers of enforcement at their disposal. Not even the basic rights of Spanish mariners could be protected sufficiently. ${ }^{54}$

Foronda's lengthy recommendations, often accompanied by sample passports and other suggested forms, fell on the proverbial deaf ears. Certain officials in Cuba even refused to acknowledge receipt of his letters for nearly a year! Obviously, despite their formal instructions, they could ill afford to turn away American ships laden with vital provisions

\footnotetext{
${ }^{52}$ The policy of allowing American ship captains to sell cargoes of flour if they also brought in slaves was on the books as early as 1789 . Foronda was especially disturbed by the American practice of transporting only four or five young black males from the Danish or Dutch islands and then demanding payment in sugar or specie. This put an additional strain on the Bourbon imperial economy without satisfying the problem of a labor shortage in Cuba: VF to PC, Phila., 7 Apr. 1803, AGI, IG, leg. 1604. Perceptive observer that he was, Foronda also recognized that some Americans had ambivalent thoughts about slavery in general and the slave trade in particular: VF to PC, Phila., 8 Nov. 1803, AHN, Estado, leg. 6175 bis.

${ }^{53}$ Pointing out that it was the foreigners who always profited from these deals, Foronda proposed a four-year moratorium on the resale of ships that were purchased for the Spanish merchant marine. Otherwise, a 25 percent tax should be levied: VF to PC, Phila., 23 Jun. 1803 , AHN, Estado, leg. 6175 bis. Ship captains, he said, should be held directly responsible for most infractions, and fines should be set at between 1,000 and 2,000 pesos: VF to PC, Phila., 3 Jan. 1803, AGI, IG, leg. 1604.

54 VF to PC, Phila., 29 Mar. and 7 Apr. 1803, AGI, IG, leg. 1604. Foronda genuinely cared about the welfare of sick Spanish mariners: VF to PC, Phila., 27 Dec. 1802 and 12 Oct. 1804, AHN, Estado, leg. 6175. Nevertheless, his problems in Philadelphia paled beside those of his American counterpart stationed in Santiago de Cuba. Not only did imperial officials refuse to recognize this agent formally; local administrators at one point threw him in jail: Josiah Blakeley to James Madison, Santiago de Cuba, 1 Nov. 1801, Dispatches from the United States Consuls in Santiago de Cuba, 1799-1906, National Archives of the United States, microcopy no. T-55, Washington, D.C., 1959, roll 1, vol. 1. Each side tried to limit the powers of the other's consuls, which strained relations even further. See also Nichols, "Trade Relations and the Establishment of United States Consulates," 289-313.
} 
and agricultural implements. Faced with food shortages, both chronic and acute, the intendant of Cuba continued to issue his own licenses for purchasing expeditions in the United States. Moreover, local planters insisted that American ships were needed to carry away spoilable Cuban products in a timely fashion. ${ }^{55}$ Likewise, in Spain, an unidentified imperial bureaucrat ridiculed Foronda's 1803 memorandum and justified official laxness and indiscretion point by point. The critic specifically advised that the consul general follow in his predecessors' footsteps and refrain from introducing any dreaded "innovations." ${ }^{6}$ In short, at least some peninsular bureaucrats had already given up, surrendering, in effect, Spain's colonial commerce to the United States. With the disastrous political situation at home, this was hardly surprising. Still, in the one instance when they tried to make life difficult for American traders-by refusing to recognize U.S. consuls resident in Cuba-they only served to undermine even further Foronda's efforts to seek redress for Spanish grievances through the American courts.

Aside from their inroads into Cuban commerce, American merchants likewise capitalized on the apparent dependence of the Spanish peninsula itself on American products. This is graphically illustrated in Foronda's annual reports. To take the year 1806 as an example, the dimensions of Spanish reliance upon American shipping and supplies were staggering. There was some good news for Spain, as Foronda strained to point out. The 191 American ships that carried cargoes directly from the United States to the Spanish peninsula actually represented a decline of some fifty sailings annually over the previous two years. Likewise, the number of barrels of flour, bushels of corn, and quintals of tobacco had dropped markedly, if only temporarily. However, the amount of codfish that Spain imported from New England continued to increase, as did the quintals of cacao carried by American vessels to Spain from its own colonies.

If the Spanish metropolis itself relied to such an extent upon American shipping, its colonies were dependent to an even greater degree. An estimated 600 ships from the United States officially entered Cuba in 1806. And whereas only 14 vessels had docked formally at other SpanishAmerican ports in 1804, at least 153 arrived a scant two years later. From other evidence, it is clear that this accelerating trend continued

${ }^{55}$ Peter James Lampros, "Merchant--Planter Cooperation and Conflict: The Havana Consulado, 1794-1832" (Ph.D. diss., Tulane Univ., 1980), esp. 278-79, 312.

${ }^{56}$ This recommendation ("sin inovar") appears in the following file: Minister of State to VF, Aranjuez, Mar. 14, 1803, AGI, IG, leg. 1604. A few months later, possibly the same unjdentified advisor wrote: "se sirva prevenirle que siga en los mismos términos que sus antecesores sin causan molestías al poco comercio que tenemos." [?] to PC, Aranjuez, 2 Jun. 1803, AGI, IG, leg. 1604. 
throughout the next decade. ${ }^{57}$ American exports consisted mainly of a wide variety of provisions and simple construction materials. Foronda also calculated the number of American ships that were purchased by Spanish nationals. The extent to which these transactions should be credited to Americans, however, is obscured by the consul general's own admission that some were accomplished in name only, so as to circumvent entry restrictions upon foreign vessels in Spanish imperial ports. On the other hand, Foronda did not include in his estimates those ship sales, legitimate and otherwise, that occurred outside the United States.

That trading contacts were extensive between the United States and the Spanish Empire comes as no surprise to those who peruse The American State Papers. ${ }^{58}$ But Foronda's correspondence offers additional insights regarding the distribution of this trade among the various American ports. From 1779 to roughly 1799, much of the available qualitative documentation suggests that U.S. trade to Cuba was centered in Philadelphia. ${ }^{59}$ Yet, as of 1804, Foronda's data indicate that most of the other larger U.S. ports enjoyed a healthy trade with Cuba as well. To use the year 1806 as an example, Foronda counted 97 departures for Cuba from Philadelphia alone, with Baltimore a close second at $90 .{ }^{60}$ However, over 100 ships returned from Cuba to each of the following ports in descending order: New York, Philadelphia, Boston, and Baltimore. At the same time, Charleston sent out 73 ships and welcomed in 95 vessels. Norfolk, Alexandria, and Savannah also were nurturing their respective contacts with Cuba, as witnessed by Foronda's haste to dispatch consuls to these smaller, southern ports. Of course, declared ship traffic is but one measurement of participation in trade. Yet whether one examines either the quantity of provisions sent (when reported) or the number and tonnage of ships sold to Spaniards, one point clearly emerges. All major American ports were vitally involved with Cuban and other Spanish imperial ports during the critical period of the Napoleonic Wars.

${ }^{57}$ Trade data and trends are laid out in chs. 2, 4, and 5 of Linda Kerrigan Salvucci, "Development and Decline: The Port of Philadelphia and Spanish Imperial Markets, 1783-1823" (Ph. D. diss., Princeton University, 1985).

${ }^{58}$ Walter Lowrie and Matthew Clarke, eds., American State Papers, Class IV, Commerce and Navigation, 2 vols. (Washington, D.C., 1832); most of these documents also appear in the first several volumes of The New American State Papers: Commerce and Navigation, with an introduction by Stephen E. Salsbury, 47 vols. (Wilmington, Del., 1973).

${ }^{59}$ As consul general, Foronda's place of residence was not fixed. However, after talking with traders once he disembarked in Boston, he had chosen Philadelphia because, he concluded, it was at the center of mercantile activities: VF to PC, Boston, 10 Jan. 1802, AHN, Estado, leg. 6175.

${ }^{60}$ U.S. customs records indicate that 117 ships cleared at Philadelphia for all Cuban ports that year: L. K. Salvucci, "Development and Decline," 325-26. 


\section{Linda K. Salvucci / 806}

The consul general's qualitative assessments are readily confirmed by other, more quantifiable data. In the 1980 s, estimates by a Spanish economist again attested to the aggregate significance of this trade. Following an export-led growth model, Javier Cuenca Esteban argued that net surpluses with the Spanish Indies and the Philippines between 1790 and 1811 covered at least nine-tenths of American deficits with the rest of the world. Along with regional gains to the various port economies, then, this "timely windfall" also went a long way toward reducing the international indebtedness of the young United States. ${ }^{61}$

During his five-year tenure as consul general, Foronda labored mightily, but he could do little to stem the rising tide of commercial contacts between the United States and Spanish America in general and between Philadelphia and Cuba in particular. His efforts to tighten up the Bourbon trading system failed, and even his attempts to augment the royal coffers had little lasting effect. In the short run, he may have diverted some of the Spanish colonial trade away from the port of Philadelphia, since Irujo, his immediate superior, sought to hide from close scrutiny his own deep involvement in American trading ventures. ${ }^{62}$ In his early squabbles with Irujo, Foronda triumphed, replacing him as chargé d'affaires in 1807. But if these smaller battles were won, then the larger struggle was lost. By the spring of 1809 , Foronda's "liberal" sympathies raised concerns among his peninsular superiors. Reports from a disgruntled subordinate and rumors fanned by English diplomatsperhaps the greatest tribute to his perspicacity-soon resulted in his recall to Spain. ${ }^{63}$

As Foronda prepared to return home, he accelerated his cherished correspondence with a fellow member of the American Philosophical Society, Thomas Jefferson. But even as the newly retired president replied cordially to Foronda's letters, Jefferson also simultaneously spelled out for others his hopes regarding the Spanish West Indies. The calculated, if not cynical, tone of his remarks no doubt reflects an understanding of

${ }^{61}$ Cuenca Esteban, "Trends and Cycles," 540-41.

${ }^{62}$ VF to MCS, Phila., 16 Jun. and 21 July 1806, AGI, IG, leg. 1603. The prominent Philadelphian John Craig was identified as Irujo's "íntimo amigo," "su socio de comercio en varias operaciones mercantiles. . . ." Foronda alleged that several departures from Boston, New York, and Baltimore were deliberately hidden from him.

${ }^{63}$ Felipe Fatio to PC, Phila., 18 Apr. 1809, AHN, Estado, leg. 6172, along with adjacent undated notes. Fatio, whose salary Foronda had withheld, claimed that conversations with some American citizens in New York led him to characterize the consul general's principles as follows: "son tan flexibles que como la giralda de Sevilla se dexa torzer segun los vientos." Additional material related to this quarrel appears in Fatio to PC, Phila., 4 May 1809, Fatio to Martín de Garay, Phila., 27 and 30 Jun., 20 July, 2 and 9 Sept. 1809, AHN, Estado, leg. 6172. Also see Manuel Hernández González, "Comercio hispanoamericano e ideas afrancesadas: en torno a la polémica entre Valentín de Foronda y Francisco Caballero Sarmiento en Filadelfia (1808-10)," Cuadernos de Investigación Histórica 13 (1990): 93-102. 
the Cuba trade that dated back to his tenure as secretary of state in the 1790 . By 1809 , Jefferson was certain that the Floridas were "ours" and that Napoleon would "consent to our receiving Cuba into our Union...." Over the next decade, his conviction grew that "Cuba will join us and give us sugar," since three-fourths of Havana's exports already came to the United States. ${ }^{64}$ By 1823, there were several admissions like the following: "I candidly confess, that I have ever looked on Cuba as the most interesting addition which could ever be made to our system of States." ${ }^{5}$ With this, John Quincy Adams emphatically agreed. In a passage routinely quoted by Spanish Americans even to this day, the secretary of state declared that "Cuba ... has become an object of transcendent importance to the commercial and political interests of our Union.... It is scarcely possible to resist the conviction that the annexation of Cuba to our republic will be indispensable to the continuance and integrity of the Union itself." ${ }^{\prime 6}$ On this occasion, however, Foronda did not comment upon such impudent American sentiments. In one of those ironic historical coincidences, he died in 1823 , just as the Monroe Doctrine was enunciated. ${ }^{67}$

\section{Conclusion}

Both Foronda's bureaucratic correspondence and his published works underscore the significant role that the Cuban market played in American commercial prosperity at the turn of the nineteenth century. They, along with Rendon's memorials, indicate that Lord Sheffield's predictions were flawed, above all by his failure to take into account the existence of a substitute or alternative market to the British West Indies for U.S. domestic produce. Yet Foronda's observations suggest far more with regard to the narrowness of Sheffield's vision. In general, the writings of Valentín Foronda recognize the value of the human and physical capital accumulated by the Philadelphia merchants he sought so vainly to control. In particular, they allow us to appreciate fully the origins and extent of the trade between the United States and Cuba.

\footnotetext{
${ }^{64}$ Andrew A. Lipscomb, ed., The Writings of Thomas Jefferson (Washington, D.C., 1903): Thomas Jefferson (hereafter TJ) to VF, Monticello, 4 Oct. 1809, vol. 12, 318-21; TJ to James Madison, Monticello, 16 Aug. 1807, vol. 11, 326-27, and 27 Apr. 1809, vol. 12, 274-77; TJ to Henry Dearborn, Monticello, 5 Jul. 1819, vol. 19, 270-72; TJ to James Monroe, Monticello, 23 Jun. 1823, vol. 15, 452-54.

${ }^{65}$ Lipscomb, ed., Writings of Thomas Jefferson: TJ to James Monroe, Monticello, 11 Jun. 1823 , vol. 15 , pp. $435-38$, and 24 Oct. 1823 , vol. 15 , pp. $477-8$ o.

${ }^{66}$ Adams expressed these views in a letter written to the American minister in Spain on 28 Apr. 1823; they are quoted at length in Charles E. Chapman, A History of the Cuban Republic: A Study in Hispanic-American Politics (Westport, Conn., rep. 1971 [c. 1927]), 51.

${ }^{67}$ For Foronda's last years, see Smith, "Valentín de Foronda," 432-35.
} 
Reciprocal comparative advantages led to the integration of these rapidly expanding markets. Philadelphia's growing hinterland and transatlantic networks allowed the region to supply Cuba with needed foodstuffs precisely as the island underwent its first "sugar revolution." More to the point, these processes occurred outside the control of imperial policymakers, either Spanish or British, thus underscoring the breakdown of mercantilist empires during the half-century after $1763 .{ }^{68}$

An Atlantic approach to early American commerce not only serves to fill in gaps in the basic story but also to connect the work of business and economic historians to broader analyses of the American past. For example, such an outlook attests to the privileged material circumstances under which the United States was born. Robert Morris and Alexander Hamilton certainly understood the extent to which fiscal stability would enhance the political stability of the new nation. It was, to be sure, a reality that eluded most Latin American counterparts, even as Mexican silver continued to flow northward. But to those who read Rendon's and Foronda's assessments of the commercial capacities of the new United States, all this should have come as little surprise.

An Atlantic perspective also raises interesting issues relating to the nature and consequences of British colonialism. If imperial administrators in London did not know how to think triumphantly after 1763 , they clearly had acquired a ruthless streak in the wake of the American war. Once the political bonds between metropolis and colonies were severed by mainland revolutionaries, the British struggled to exploit their remaining West Indian colonies in the face of economic stagnation and decline. The precise dating of these trends has been the subject of considerable scholarly efforts, but a larger point is now evident. ${ }^{69}$ The "decline" of the British Caribbean corresponded with the "rise" of the Spanish West Indies. In this context, the collective activity of early American merchants in Cuba was sweet revenge, as they quickly demonstrated that an alternative existed to Jamaica and other British island markets. Even more to the point, the politics of the British antislavery movement coincided with the emergence of a more efficient producer of sugar, namely Cuba. As metropolitan activists focused their energies on emancipation in the British West Indies, Cuba was able to

\footnotetext{
${ }^{68}$ François Crouzet, "America and the Crisis of the British Imperial Economy, 18031807," in McCusker and Morgan, eds., The Early Modern Atlantic Economy, 278-315, highlights Great Britain's difficulties in enforcing a restrictive trade policy during the Napoleonic years. See Silvia Marzagalli's article in this issue of the Business History Review for an analysis of increased French trade with former British colonies.

${ }^{69}$ See the works and their bibliographies cited in note 30 , as well as David Beck Ryden, "Does Decline Make Sense? The West Indian Economy and the Abolition of the British Slave Trade," Journal of Interdisciplinary History 31 (Winter 2001): 347-74.
} 
ensure its labor supply by importing ever more slaves from Africa. ${ }^{70}$ So long the beneficiaries of preferential treatment within the empire, British West Indian planters were now deprived of vital food supplies from the U.S. mainland that, to make matters worse, were redirected to Cuba, their most serious competitor. Ultimately, the coup de grâce for the British West Indies came in 1846, when Great Britain abolished preferences for British Caribbean sugar, thereby granting metropolitan consumers ready access to the Spanish West Indian product! In other words, in an ironic twist of the Williams thesis, British policymakers attempted to forestall potential worker unrest at home at the expense of their once-favored colonial producers. ${ }^{71}$ It was they who paid the price for Lord Sheffield's punitive strategy, while Americans cemented a crucial commercial relationship with Cuba, one that ultimately ushered in a new age of imperialism.

${ }^{70}$ David R. Murray, Odious Commerce: Britain, Spain and the Abolition of the Cuban Slave Trade (Cambridge, 1980), and Eltis, Economic Growth and the Ending of the Transatlantic Slave Trade, cited above in note 1.

${ }^{71}$ Eric Williams, Capitalism and Slavery (Chapel Hill, 1944), and Sidney Mintz, Sweetness and Power: The Place of Sugar in Modern History (New York), 1985. 